\title{
LONG-TERM TAX COMPETITIVENESS OF THE NEW EU MEMBER STATES COMPARED TO THE ORIGINAL EU MEMBERS
}

\author{
[Dlouhodobá daňová konkurenceschopnost nových členských států EU \\ v porovnání s původními členy EU]
}

\author{
Květa Kubátová ${ }^{1}$ \\ ${ }^{1}$ Vysoká škola ekonomická v Praze, Fakulta financí a účetnictví, n. W. Churchilla 4, 13067 Praha 3 \\ Email:kubatova@vse.cz
}

\begin{abstract}
The article aims to find out which countries were in the period from 1995/1996 to 2008/2009 competitive in personal income tax, corporate tax and VAT and whether the postcommunist countries show a different level of competitiveness. Competitiveness is measured using the method of constant tax shares when countries incurring its share in total tax revenue across the region are classified as competitive. The difference in competitiveness indicators between the examined two groups of states is then determined using the analysis of variance (ANOVA). The results show that the influence of competitiveness implicated revenue growth of individual taxes and individual countries, both positive and negative. The Baltic States are the most tax-competitive and also other post communist states have good competitiveness. By contrast, Germany remains by this method the least tax competitive country in the EU. The analysis also showed that post-communist countries are in the long period in average more tax-competitive than the original members of the EU in personal income tax and VAT. But the test was statistically insignificant in the case of corporation tax.
\end{abstract}

Keywords: ANOVA, constant tax shares method, corporation tax, personal income tax, tax competitiveness, VAT.

JEL classification: $\mathrm{H} 20$

Doručeno redakci: 16.5.2013; Recenzováno: 4.6.2013; 21.5.2013; Schváleno k publikování: 16.6.2014

\section{Úvod}

Článek se zabývá měřením daňové konkurenceschopnosti zemí Evropské unie a identifikací rozdílů mezi dvěma skupinami států v tomto společenství. První skupinou jsou původní členské státy a druhou jsou postkomunistické státy, které se staly členy v letech 2004 a 2006 (Dva noví členové z roku 2004, Kypr a Malta v analýze zastoupeny nejsou proto, že potřebná data nejsou pro ně k dispozici).

Cílem článku je zjistit, které státy jsou dlouhodobě konkurenceschopné u daně osobní důchodové, daně korporativní a DPH a zda postkomunistické státy vykazují odlišnou míru konkurenceschopnosti. Konkurenceschopnost je měřena pomocí metody konstantních daňových podílů, kdy státy navyšující svůj podíl v celkovém daňovém výnosu celého regionu, jsou označeny jako konkurenceschopné. Rozdílnost v ukazateli konkurenceschopnosti mezi zkoumanými dvěma skupinami států je pak zjišt'ována pomocí metody analýzy rozptylu (ANOVA).

Článek je organizován následovně. Nejprve je stručně uveden problém daňové konkurence mezi státy, následuje popis použité metody konstantních daňových podílů a použitých dat. Poté jsou prezentovány výsledky analýz postupně pro jednotlivé daně a nakonec jsou výsledky shrnuty do Závěru. 


\section{Daňová konkurence}

Daňovu konkurencí se rozumí stanovení takových daní, aby pro daňové poplatníky bylo výhodné přesunout mobilní daňové základy pod danou legislativu, resp. vykázat je v dané zemi. Státy si daňově konkurují v podmínkách mobility daňových základů, tj. mobility zisků a dalších př́ijmů, prodejů a dalších základů daní. Je zřejmé, že v podmínkách jednotného trhu, ve kterém je podle Lisabonské smlouvy (Europa, 2013) zaručena mobilita zboží, osob, služeb a kapitálu může potenciálně docházet ke vzájemné daňové konkurenci mezi státy ve snaze posílit vlastní veřejné rozpočty.

Konkurence se týká nejen daní, které nejsou harmonizovány (př́mé daně), ale také daní nepř́mých, u nichž je konkurence možná pomocí stanovení sazeb, osvobození od daně a výběru základní či snížené sazby u zboží a služeb, pokud se nepřekročí rámec evropské legislativy. Veřejné rozpočty daňově konkurenceschopných států díky př́ilivu daní ze základů, které by se jinak zdaňovaly u jejich konkurentů, prospívají.

Daňová konkurence je někdy chápána jako škodlivá, nebot' snižuje možnosti vlád při zvyšování vlastních daňových př́ímů, a tudíž může podlamovat financování veřejných statků. Evropská komise se nerozpakuje nazvat daňovou konkurenci „škodlivou“ (European Commission, 1997). Mnozí autoři ji však chápou jako pozitivní bariéru pro rozpínavost veřejného sektoru a omezování rozvoje sektoru soukromého. K diskusi o škodlivosti a užitečnosti daňové konkurence viz Summers (1988), Vančurová a Láchová (2010); dopadem daňové konkurence na ekonomiku včetně metod měření daňové konkurence se zabývá Matthews (2011). Metody měření, podobně jako jiní autoři (napřr. Chen a Mintz, 2012 nebo Devereux aj., 2008) odvozuje od sazeb daní a stanovení základů daní. Jde o ukazatele vyjadřující míru zdanění, přičemž se nebere v potaz chování subjektů. Nižší zdanění je automaticky považováno za konkurenceschopnější.

Ve výše zmiňovaných analýzách a výpočtech ukazatelů daňové konkurenceschopnosti jde vždy o okamžitou konkurenceschopnost, vztahující se k jednomu roku. Chování subjektů se nezohledňuje, nelze tedy s jistotou říci, že státy s nižším zdaněním efektivně přilákaly daňové základy na své území. V předkládané analýze je tomu jinak - bude se sledovat, které státy a jak jsou skutečně daňově konkurenceschopné, čili zda jejich nastavení daní přitáhlo daňové základy (zisky, př́ijmy a spotřebu) pod jejich daňovou legislativu, takže relativně posílily výnosy vybraných daní. Tuto metodu můžeme nazvat metodou konstantních daňových podílů. Analýza bude sledovat dlouhodobé změny, a to od roku 1995/1996 do období 2008/2009. Státy, které se více zapojily do celounijního výběru určité daně budou považovány za více konkurenceschopné.

Metoda má kromě uvedené přednosti i své limity, které musí být zohledněny při interpretaci výsledků. Zvýšené výnosy daní mohou být totiž způsobeny nejen konkurenceschopností státu, ale také zvýšením sazby, rozšiřrením základů nebo zvýšenou kontrolou při současné nemobilitě základů. Základy daně totiž nemusí být plně mobilní a subjekty mohou i po zvýšení daně zůstat ve své zemi, když nedaňové výhody převáží.

\section{Metoda konstantních daňových podílů}

Metoda konstantních daňových podílů je aplikací známé metody konstantních tržních podílů na daňovou oblast. Autorka ji popsala a použila již v dřívějších pracích, např. Kubátová (2009). 
Metoda konstantních tržních podílů porovnává vývoj exportu dané země s „,normou“. Spočívá v rozkladu přírůstků exportu země na složky připisované různým vlivům. Metodu (v angl. constat-market-share-method) odvodil Tyzsinski (1951), formální zápis metody rozvinul Richarson (1971). V novější době použili tuto metodu např́klad Edward, Chen and Kuy WaiLi (1994) nebo Weiguo Lu (1996).

Metoda konstantních tržních podílů je klasickou metodou, která se používá k měření exportní výkonnosti země. Růst podílu země na celkovém vývozu konkurenčních zemí (světa nebo omezeného teritoria) se rozkládá na čtyři vlivy. Těmi jsou vliv růstu světového exportu, vliv komoditní struktury vývozu dané země, vliv teritoriální struktury této země a tzv. „reziduum“. Toto reziduum se interpretuje jako vliv „konkurenceschopnosti““.

Pro tuto práci se použije zápis podle Kubátové (2009) a Richarsona (1971) ${ }^{1}$ a analogicky se metoda vztáhne nikoliv na exportní výkonnost, ale na tzv. „daňovou výkonnost“. Nejdříve bude metoda popsána pro exportní výkonnost země, následně bude zavedena analogie pro daňové výnosy spolu s jejím zdůvodněním.

Označíme:

$\mathrm{v}_{\mathrm{i}}$ - export země $\mathrm{i}$

E - celkový export konkurentů

$\mathrm{s}_{\mathrm{i}}=\mathrm{v}_{\mathrm{i}} / \mathrm{E}-$ exportní podíl země i na celkovém trhu

$\mathrm{c}_{\mathrm{i}}-$, ,konkurenceschopnost"“ země i

$\mathrm{C}-$ „konkurenceschopnost“" všech konkurentů

$\mathrm{c}_{\mathrm{i}} / \mathrm{C}-$ „relativní konkurenceschopnost“" země i

Pokud předpokládáme, že exportní podíly dané země jsou funkcí „relativní konkurenceschopnosti“, můžeme dále zapsat:

$$
\mathrm{s}_{\mathrm{i}}=\mathrm{v}_{\mathrm{i}} / \mathrm{E}=\mathrm{f}_{\mathrm{i}}\left(\mathrm{c}_{\mathrm{i}} / \mathrm{C}\right)
$$

Úpravou potom dostaneme:

$$
\mathrm{v}_{\mathrm{i}}=\mathrm{s}_{\mathrm{i}} \mathrm{E}
$$

Všechny tři výrazy v rovnici (2) mohou být chápány jako funkce času, derivací podle proměnné času vznikne výraz:

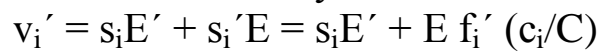

[1] [2]

kde $v_{i}^{\prime}, E^{\prime}, f_{i}^{\prime}\left(c_{i} / C\right)$ jsou první derivace proměnných (funkce) podle času $t$.

Výraz [1] v rovnici (3) vyjadřuje, jaký by byl př́riostek exportu země i, pokud by si zachovala exportní podíl, výraz [2] vyjadřuje každý další prŕirůstek exportu země i vlivem konkurenceschopnosti.

Pro praktické použití je třeba rovnici (3) přepsat pro diskrétní časovou proměnnou:

$$
\Delta \mathrm{v}_{\mathrm{i}}=\mathrm{v}_{\mathrm{i}}{ }-\mathrm{v}_{\mathrm{i}}^{0}=\mathrm{s}_{\mathrm{i}}^{0} \Delta \mathrm{E}+\mathrm{E}^{1} \Delta \mathrm{s}_{\mathrm{i}}
$$

$$
\text { [1] [2] }
$$

Index 0 zde značí výchozí období a index 1 běžné období.

Stejně tak platí:

$$
\Delta v_{i}=v^{1}{ }_{i}-v^{0}{ }_{i}=s^{1}{ }_{i} \Delta E+E^{0} \Delta s_{i}
$$

\footnotetext{
${ }^{1} \mathrm{~K}$ této metodě viz bliže Kubátová (1983)
} 
Teoreticky jsou rovnice (4) a (5) k analýze stejně použitelné, záleží pouze na tom, co použijeme jako normu podílu dané země na celkovém exportu. Tou může být její podíl ve výchozím nebo běžném období ${ }^{2}$. Většinou se používá první verze, tj. rovnice (4), která bude použita i v této analýze.

Nyní se dostáváme k provedení analogie výnosů daní s exportem. Tak jako je export jedné země dílem exportu celkového, tak můžeme chápat i výnosy daní jedné země jako podíl celkových výnosů této daně ve všech státech. Obzvláště je to takto možné chápat v globálním světě, kde mobilita základu daně umožňuje vyhýbání se zdanění v zemi s větší zátěží. Základ daně je možné přesunout do výhodnějších teritorií. Analogie se světovým vývozem je tak nasnadě. Export jedné země závisí na růstu celkového exportu (výraz [1] v rovnici (4)) a „exportní konkurenceschopnosti““ země (výraz [2] v rovnici (4)) a stejně tak závisí výnosy daně jedné země na růstu celkových výnosů této daně a její „,daňové konkurenceschopnosti“.

Pro analogii označíme výrazy rovnice:

$\mathrm{t}_{\mathrm{i}}$ - výnosy daně jedné země

$\mathrm{T}$ - výnosy daně konkurenčních zemí

$\mathrm{S}_{\mathrm{i}}=\mathrm{t}_{\mathrm{i}} / \mathrm{T}-$ podíl země na celkových výnosech daně

Analogická rovnice rovnici (4) pro daňovou výkonnost potom vypadá následovně:

$$
\Delta \mathrm{t}_{\mathrm{i}}=\mathrm{t}_{\mathrm{i}}^{1}-\mathrm{t}_{\mathrm{i}}^{0}=\mathrm{s}_{\mathrm{i}}^{0} \Delta \mathrm{T}+\mathrm{T}^{1} \Delta \mathrm{s}_{\mathrm{i}}
$$

$$
\text { [1] [2] }
$$

Index 0 opět značí výchozí období a index 1 běžné období.

Výraz [1] na pravé straně rovnice vyjadřuje vliv celkového růstu výnosu daně a výraz [2] vliv „daňové konkurenceschopnosti““.

V tomto článku budou analýze podrobeny tři druhy daní, a to daň z osobních důchodů, daň $\mathrm{z}$ příjmů korporací a daň z přidané hodnoty.

\section{Použitá data}

Metoda konstantních daňových podílů pracuje s daňovými výnosy ve dvou sledovaných obdobích. Výchozí období analýzy jsou léta 1995 a 1996 a běžným obdobím léta 2008 a 2009. V obou př́padech se pracuje s dvouletými průměry kvůli zmírnění náhodných výkyvů. Použitými statistikami jsou Taxation trends (2011), které poskytují údaje o podílech jednotlivých daní na HDP a databáze Eurostatu, ze které byly převzaty údaje o HDP.

Pro analýzy byly z daňových mixů vybrány tři daně - daň z př́ijmů jednotlivců, daň z př́ijmů korporací a daň z přidané hodnoty. Tento výběr byl proveden na základě úvahy o možnostech zkoumání vlivu konkurenceschopnosti. Jde o daně, které jsou v daňových mixech obecně silně zastoupeny a zároveň mají mobilní základ, který potenciálně podléhá mezinárodní konkurenci.

Data jsou k dispozici pro 24 zemí v případě přímých daní a 23 zemí v případě nepřímých daní. Do analýzy nebyly zahrnuty Řecko, Kypr a Malta, u DPH pak ani Slovinsko.

\section{Výsledky}

Vzorec 4 byl aplikován na tři daně - osobní důchodovou daň, daň ze zisku korporací a DPH.

\footnotetext{
${ }^{2}$ K této metodě viz blíže Kubátová (1983)
} 
Vliv celkového růstu výnosů a vliv konkurenceschopnosti u osobní důchodové daně ukazuje u jednotlivých zemí Obrázek 1.

Obrázek 1: Vliv celkového růstu výnosů a vliv konkurenceschopnosti na růst výnosů osobní důchodové daně v jednotlivých zemích EU

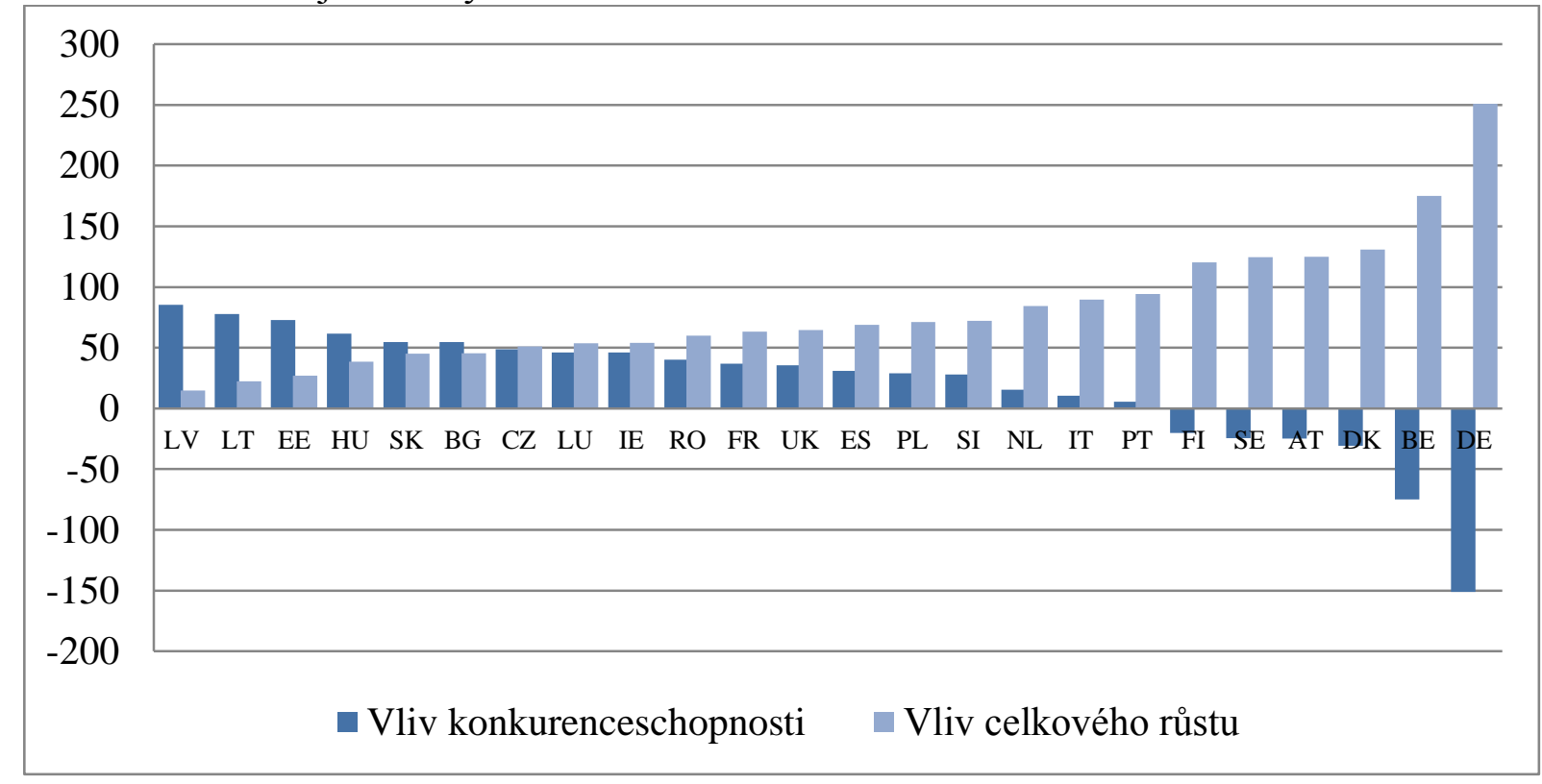

Pozn.: 24 zemí EU v letech 1995/1996 až 2008/2009 (v \%), data pro Řecko, Kypr a Maltu nejsou k dispozici. Zdroj: Taxation trends (2011), Eurostat (2012), vlastní výpočty

Z použité statistiky plyne, že výnosy osobních důchodových daní ve všech zemích v absolutní výši vzrostly. Na tento růst měly vliv oba sledované faktory - vliv celkového růstu výnosů a vliv konkurenceschopnosti. Vliv celkového růstu a vliv konkurenceschopnosti dohromady představují $100 \%$ celkového růstu daňových výnosů v každé zemi. Kladné hodnoty znamenají pozitivní a záporné pak negativní vliv daného faktoru.

Vliv celkového růstu daňových výnosů je v případě osobní důchodové daně u všech sledovaných zemí kladný. Znamená to tedy, že pozitivně ovlivňuje růst daňových výnosů $\mathrm{v}$ jednotlivých zemích, a to v rozmezí 15 až $251 \%$. Nejnižší hodnoty byly naměřeny u pěti postkomunistických zemí, kde se pohybuje pod 50 \%. Nejvyšší hodnoty, nad 120 \%, byly zaznamenány u šesti vyspělých kontinentálních zemí.

Když se nyní zaměříme na vliv konkurenceschopnosti, můžeme u některých zemí pozorovat záporné hodnoty. Tato situace nastává u šesti z analyzovaných zemí. Logicky se jedná o země s nejvyššími hodnotami ukazatele vlivu celkového růstu výnosů (nebot' oba vlivy dohromady tvoři $100 \%$ růstu). Nejméně konkurenceschopné se s hodnotou $-151 \%$ ukázalo být Německo. Naopak nejvyšší konkurenceschopnost byla naměřena v př́padě Lotyšska v hodnotě $85 \%$. Česká republika má oba vlivy vyrovnané, tvoří 49 a $51 \%$.

Nabízí se otázka, zda jsou postkomunistické země skutečně konkurenceschopnější než původních 15 členských států. K ověření použijeme metodu analýzy rozptylu (ANOVA). Výsledek analýzy ukazuje Tabulka 1. 
Tabulka 1: Analýza ANOVA pro konkurenceschopnost osobní důchodové daně v období 1995/1996 až 2008/2009 v zemích EU (podle typu země - původní členské země a postkomunistické země)

Analysis of Variance

\begin{tabular}{|c|c|c|c|c|c|}
\hline Source & Sum of Squares & Df & Mean Square & F-Ratio & P-Value \\
\hline Between groups & 22744,8 & 1 & 22744,8 & 11,93 & 0,0023 \\
\hline Within groups & 41955,8 & 22 & 1907,08 & & \\
\hline
\end{tabular}

Pozn.: 24 zemí EU, data pro Řecko, Kypr a Maltu nejsou k dispozici.

Zdroj: Taxation trends (2011), Eurostat (2012), vlastní výpočty na hladině významnosti 5 \% programem Statgraphics Plus.

Vzhledem k tomu, že P-value pro F-test je nižší než 0,05 , existuje statisticky významný rozdíl mezi průměrnou hodnotou koeficientu konkurenceschopnosti u původních členů EU a u členů - postkomunistických zemí.

Obrázek 2 ukazuje oba vlivy u daně ze zisku korporací u zkoumaných 24 zemí.

Obrázek 2: Vliv celkového růstu výnosů a vliv konkurenceschopnosti na růst výnosů daně ze zisku korporací v jednotlivých zemích EU

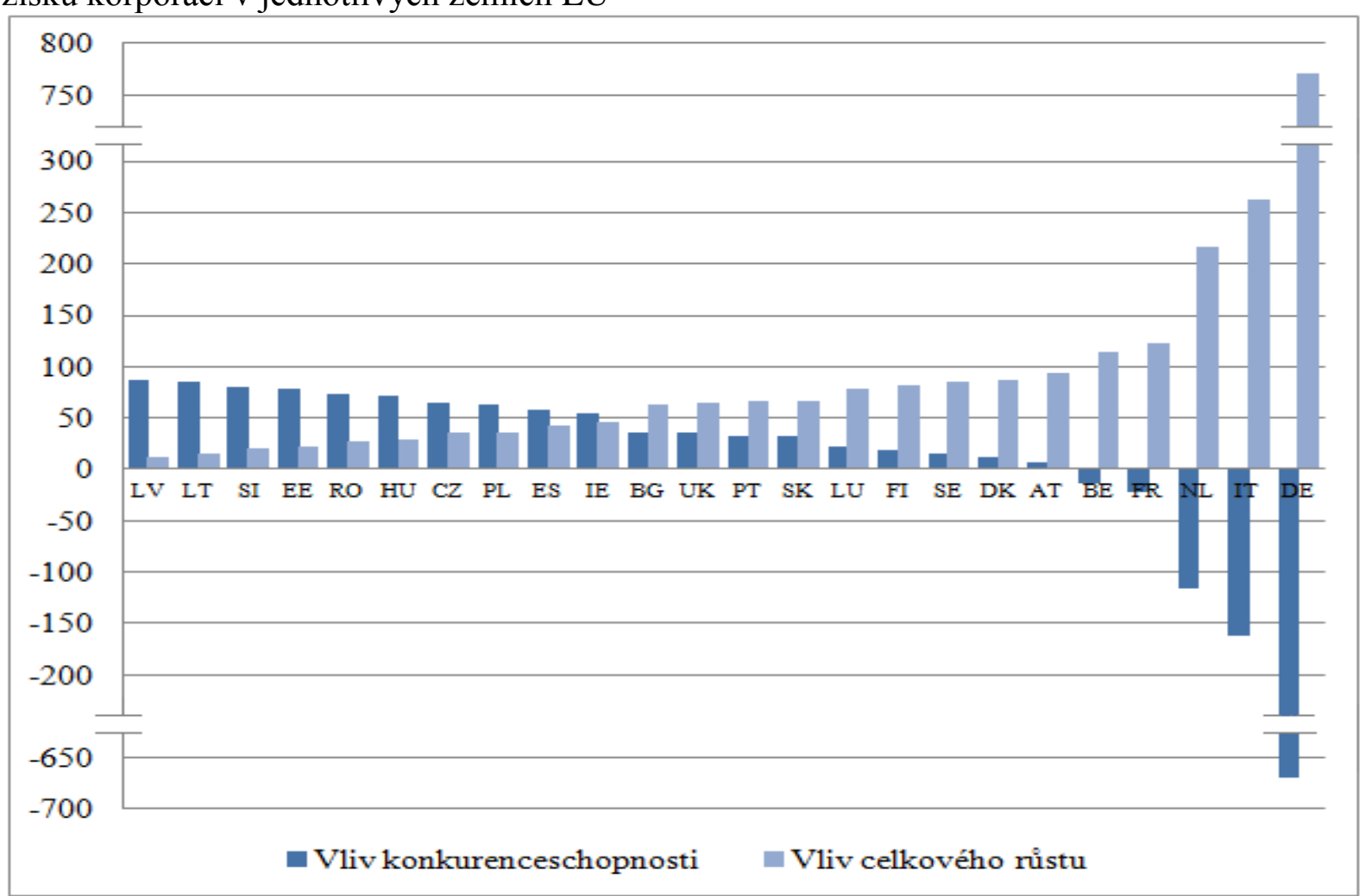

Pozn.: 24 zemí EU v letech 1995/1996 až 2008/2009 (v \%), data pro Řecko, Kypr a Maltu nejsou k dispozici. Zdroj: Taxation trends (2011), Eurostat (2012), vlastní výpočty

Stejně jako u osobních důchodových daní rostly, výnosy absolutně i v prŕípadě daní korporátních. Tento růst byl opět způsoben oběma sledovanými faktory. 
Vliv celkového růstu daňových výnosů je i v případě korporátní daně u všech sledovaných zemí kladný, a to v rozmezí 13 až $770 \%$. Hodnoty pod $50 \%$ byly naměřeny u 8 postkomunistických zemí a také u Španělska a Irska. Nejvyšších hodnot opět dosahují vyspělé kontinentální státy, z nich vůbec nejvyšší hodnotu, 770 \% má Německo.

Co se týká vlivu konkurenceschopnosti, nalezneme u některých zemí záporné hodnoty. Tato situace nastává u pěti z analyzovaných zemí, původních členů EU, přičemž Německo vyšlo i z této analýzy jako nejméně konkurenceschopné s hodnotou $-670 \%$. Naopak nejvyšší konkurenceschopnost byla naměřena $v$ př́padě Lotyšska v hodnotě 87 \%. Česká republika má v prrípadě korporátní daně silnější vliv konkurenceschopnosti, který zde činí 64 \%.

Rozdíl v dlouhodobé konkurenceschopnosti (Tabulka 2) mezi původními členskými zeměmi a postkomunistickými členy EU však na hladině významnosti nebyl statisticky významný (pvalue je větší než 0,05$)$.

Tabulka 2: Analýza ANOVA pro konkurenceschopnost daně korporací v období 1995/1996 až 2008/2009 v zemích EU (podle typu země - původní členské země a postkomunistické země)

Analysis of Variance

\begin{tabular}{|c|c|c|c|c|c|}
\hline Source & Sum of Squares & Df & Mean Square & F-Ratio & P-Value \\
\hline Between groups & 83142,2 & 1 & 83142,2 & 3,94 & 0,0598 \\
\hline Within groups & 464410,0 & 22 & 21109,5 & & \\
\hline Total (Corr.) & 547552,0 & 23 & & & \\
\hline
\end{tabular}

Pozn.: 24 zemí EU, data pro Řecko, Kypr a Maltu nejsou k dispozici.

Zdroj: Taxation trends (2011), Eurostat (2012), vlastní výpočty na hladině významnosti $5 \%$ programem Statgraphics Plus.

Jako poslední daň byla zkoumána $\mathrm{DPH}$ a rozložen růst jejich výnosů na vliv růstu celkových výnosů a vliv konkurenceschopnosti (Obrázek 3). 
Obrázek 3: Vliv celkového růstu výnosů a vliv konkurenceschopnosti na růst výnosů DPH v jednotlivých zemích EU*

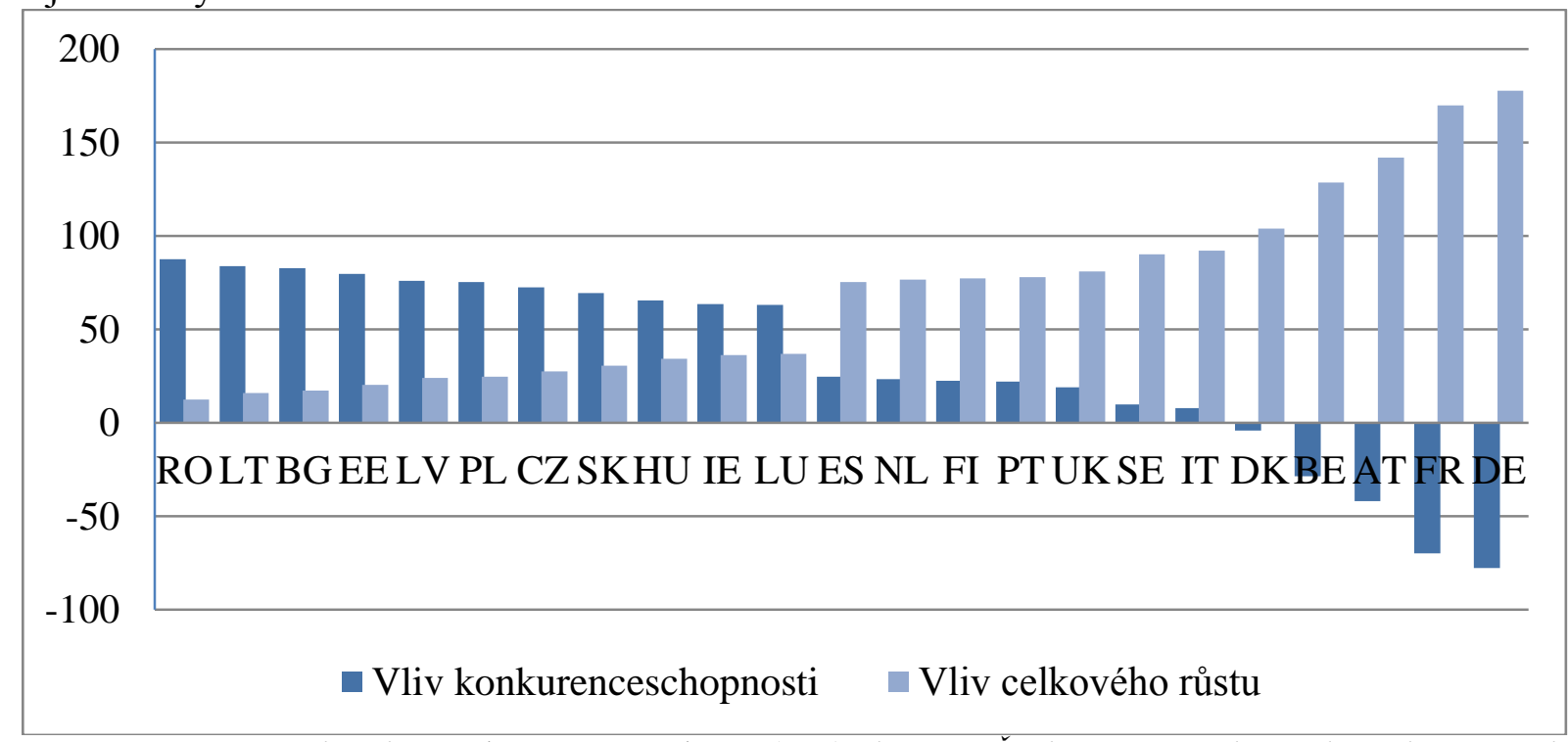

Pozn.: 24 zemí EU v letech 1995/1996 až 2008/2009 (v \%), data pro Řecko, Kypr, Maltu a Slovinsko nejsou $k$ dispozici.

Zdroj: Taxation trends (2011), Eurostat (2012), vlastní výpočty

Rovněž u DPH došlo v analyzovaném období $\mathrm{k}$ absolutnímu růstu daňových výnosů u všech zemí. To je ve všech zemích způsobeno celkovým růstem daňových výnosů. Hodnota tohoto ukazatele se pohybuje od 12 do $178 \%$. U DPH mají hodnoty pod $50 \%$ všechny postkomunistické země, a také Irsko a Lucembursko. Nejvyšší hodnoty nad $100 \%$ nalezneme u pěti kontinentálních vyspělých zemí.

Jako konkurenceschopné země vyšly z analýzy DPH všechny země kromě Dánska, Belgie, Rakouska, Francie a Německa, kde vliv konkurenceschopnosti nabývá záporných hodnot. Nejméně konkurenceschopné je Německo, tentokrát s -78 \%. Česká republika dosahuje hodnoty $72 \%$.

Tabulka ANOVA (Tabulka 3) ukazuje, že rozdíl mezi sledovanými dvěma skupinami zemí je u DPH statisticky významný. V tomto př́padě je test ANOVA proveden pro forma, nebot' statistická významnost je zřejmá už z pohledu na Obrázek 3 (země jedné skupiny mají všechny vyšší koeficient konkurenceschopnosti než kterákoliv země druhé skupiny).

Tabulka 3: Analýza ANOVA pro konkurenceschopnost DPH v období 1995/1996 až 2008/2009 v zemích EU (podle typu země - původní členské země a postkomunistické země)

Analysis of Variance

\begin{tabular}{|c|c|c|c|c|c|}
\hline Source & Sum of Squares & Df & Mean Square & F-Ratio & P-Value \\
\hline Between groups & 30464,0 & 1 & 30464,0 & 25,89 & 0,0000 \\
\hline Within groups & 24709,4 & 21 & 1176,64 & & \\
\hline
\end{tabular}

Pozn.: 24 zemí EU, data pro Řecko, Kypr, Maltu a Slovinsko nejsou k dispozici.

Zdroj: Taxation trends (2011), Eurostat (2012), vlastní výpočty na hladině významnosti $5 \%$ programem Statgraphics Plus. 


\section{Závěr}

Článek zkoumal pomocí metody konstantních daňových podílů vliv konkurenceschopnosti zemí EU na růst jejich daňových výnosů u tří daní v období 1995/1996 až 2008/2009. Daňovou konkurenceschopností je myšlena schopnost státu přilákat pod svou legislativu základy daní a tím zvýšit své daňové výnosy. V souladu s výrazem [2] v rovnici (4) je daňově konkurenceschopná ta země, která relativně zvýší svůj podíl na daňových výnosech regionu za určité období.

Daňové výnosy ve všech zemích u všech sledovaných daní rostly. Na tento růst měla ve všech př́padech pozitivní vliv složka celkového růstu výnosů v regionu. Vliv konkurenceschopnosti měl na růst výnosů u jednotlivých daní a jednotlivých zemí jak pozitivní, tak negativní důsledky.

V př́ípadě osobní důchodové daně zápornou konkurenceschopnost mělo šest států, Belgie, Dánsko, Německo, Rakousko, Finsko a Švédsko. U korporátní daně je to pět států, Belgie, Německo, Francie, Itálie a Nizozemsko. U DPH pozorujeme zápornou konkurenceschopnost také u pěti států, Belgie, Dánska, Německa, Francie a Rakouska.

Relativně nejlépe jsou na tom Itálie, Nizozemsko, Finsko a Švédsko. U nich se zhoršená konkurenceschopnost projevila pouze u jedné daně. U dvou daní tento jev nalezneme v Dánsku, Francii a Rakousku. Zhoršená konkurenceschopnost u všech třri sledovaných daní byla naměřena $v$ prŕṕpadě Belgie a Německo. Německo se tak stalo nejméně daňově konkurenceschopnou zemí v EU podle použité metodiky.

Nejlépe naopak dopadly pobaltské země, které se u všech daní vyskytovaly na začátku žebříčku s nejvyššími hodnotami konkurenceschopnosti.

U České republiky byly naměřeny ve všech př́padech kladné hodnoty konkurenceschopnosti. Nejvyšší hodnoty (72 \%) dosáhla u DPH a nejnižší (49 \%) u osobní důchodové daně.

Analýza také ukázala, že postkomunistické země jsou dlouhodobě daňově konkurenceschopnější než původní členové EU u osobní důchodové daně a DPH, zatímco u daně korporací jejich průměrně vyšší konkurenceschopnost nebyla statisticky prokázána. To ovšem znamená, že právě u této daně, která má ze zkoumaných daní nejmobilnější základ (k mobilitě základů různých daní viz Kubátová, 2010) a která je nejvýznačnějším předmětem stimulační daňové politiky, nelze prokázat úspěšné přitahování základů pod tyto jurisdikce. $\mathrm{K}$ identifikaci, které faktory se na tomto vývoji podílejí, by byla však potřebná další analýza.

\section{Poděkování}

Př́spěvek je zpracován jako jeden $\mathrm{z}$ výstupů $\mathrm{v}$ rámci řešení výzkumného projektu, podporovaného institucionální podporou IP 100040 na Fakultě financí a účetnictví Vysoké školy ekonomické v Praze.

\section{Literatura}

[1] DEVEREUX, M. P., Ch. ELSCHNER, D. ENDERS, J. H. HECKENMEYER, M. OVERERSCH, U. SCHREIBER and Ch. SPENGEL, 2008. Corporate Effective Tax Rates in an Enlarged European Union. Centre for European Economic Research [online]. [vid. $1 . \quad$ záŕí 2011]. Dostupné z: http://ec.europa.eu/taxation_customs/resources/documents/taxation/gen_info/economic_a nalysis/economic_studies/effective_levels_report.pdf 
[2] EDWARD, K. Y., CHEN and KUY WAI-LI, 1994. Manufactured Export Expansion in Hong Kong and Asian-Pacific Regional Cooperation. In: Manufactured Exports of East Asian Industrializing Economies. Ed. by Shu Chin Yang. Business \& Economics, 1994, $274 \mathrm{~s}$.

[3] EUROPA, 2013. Lisabonská smlouva, smlouva pro Evropu 21. století. [on-line]. [vid. 5. května 2013]. Dostupné z: http://europa.eu/lisbon_treaty/index_cs.htm

[4] EUROPEAN COMMISSION, 1997. Harmful Tax Competition. [online]. 2. květen 2012 [vid. $7 . \quad$ května. 2013]. Dostupné z: http://ec.europa.eu/taxation_customs/taxation/company_tax/harmful_tax_practices/

[5] EUROPEAN COMMISSION, 2011. Taxation Trends in the European Union 2011. [online]. 5. května 2012 [vid. 10. května 2012]. Dostupné z: http://ec.europa.eu/taxation_customs/taxation/gen_info/economic_analysis/tax_structures /index_en.htm

[6] EUROSTAT - databáze, 2012. [online]. 4. květen 2012 [vid. 7. května 2012]. Dostupné z: http://appsso.eurostat.ec.europa.eu/nui/show.do?dataset=nama_gdp_k\&lang=en

[7] CHEN, D. and J. MINTZ, 2012. Corporate Tax Competitiveness Rankings for 2012. Tax and Budget Bulletin. No. 65, Cato Institute. [online]. záŕí 2012 [vid. 7. května 2013]. Dostupné z: http://www.cato.org/sites/cato.org/files/pubs/pdf/tbb_65.pdf

[8] KUBÁTOVÁ, K., 1983. Metody analýzy československé exportní výkonnosti. Kandidátská dizertační práce. Ekonomický ústav ČSAV, Praha, 168 s.

[9] KUBÁTOVÁ, K., 2009. Analýza daňové konkurenceschopnosti u daně z př́jmů korporací v EU. Praha 03. 04. 2009 - 04. 04. 2009. In: Teoretické a praktické aspekty veřejných financi [CD]. Praha: Nakladatelství Oeconomica, 2009, s. 22. ISBN 978-80245-1513-7.

[10] KUBÁTOVÁ, K., 2010. Daňová teorie a politika. 5. aktual. vyd. Praha: Wolters Kluwer, 2010. 275 s. ISBN 978-80-7357-574-8.

[11] MATTHEWS, S., 2011. What is a "Competitive" Tax System? OECD Taxation Working Papers, No. 2. OECD Publishing. [online]. [vid. 5. 5. 2013]. Dostupné z: $10.1787 / 5 \mathrm{~kg} 3 \mathrm{~h} 0 \mathrm{vmd} 4 \mathrm{kj}$-en

[12] RICHARDSON, J. D., 1971. Constant-Market-Share Analysis of Export Growth. Journal of International Economics, vol. 1, May 1971, 227-239.

[13] SUMMERS, L., H., 1988. Tax Policy and International Competitiveness. In: International Aspects of Fiscal Policies. Ed. By Frenkel, Jacob A., University of Chicago Press. p. 349 - 386. ISBN 0-226-26251-0. [online] [vid. 5. 5. 2013]. Dostupné z: http://www.nber.org/books/fren88-1

[14] TYZSINSKI, H., 1951. World Trade in Manufactured Commodities, 1899-1950. Manchester School of Economic and Social Studies (September)

[15] VANČUROVÁ, A. a L. LÁCHOVÁ, 2010. Daňový systém ČR 2010.10. aktualizované vydání, Praha: VOX, 356 s. ISBN978-80-86324-86-9.

[16] WEIGUO, L, 1996. Performance of Australian Merchandise Exports. In: East Asia: A Constant Market Share analysis. Research Note of the Department of the Parliamentary Library, Number 54, 25 June 1996, ISSN 1323-5664. [online] [vid. 15. 4. 2012]. Dostupné z: http://www.aph.gov.au/library/pubs/rn/1995-96/96rn54.pdf 